\title{
Fusion reactor finds delay is price of global cooperation
}

\begin{abstract}
Washington. International cooperation is supposed to be the salvation of big science, but a four-country effort to design and build the next-generation fusion test reactor shows that the outlook for such collaborations is murky as well. This week, 18 months behind schedule, the United States, European Communities (EC), Russian Federation and Japan were expected to sign an agreement for a six-year, \$1-billion engineering design phase of the International Thermonuclear Experimental Reactor (ITER).
\end{abstract}

The pact, signed in Washington, will permit the three design centres, located in San Diego, California; Garching, Germany; and Naka, Japan to begin hiring what are expected to be as many as 180 scientists and engineers and 120 support staff. The fact that three centres were required, instead of the one venue first envisioned, suggests that even bigger problems loom when the partners try to decide where to build the actual reactor. Paul-Henri Rebut, the project's director-designate, wants to settle on a site in four years. Even then, the reactor could not operate until 2005.

The partners had expected the engineering phase to flow relatively quickly from an earlier and smaller conceptual design completed in late 1990. Although an agreement was reached in principle last August eight months behind schedule - it has taken almost a year to gain the required approval of the member governments.

ITER's official cost is $\$ 5.8$ billion, although its supporters admit that the eventual price may be close to the $\$ 8.25$-billion budgeted for the Superconducting Super Collider. US officials are fond of citing that giant particle accelerator, under construction in Texas, as big science conceived and carried out the wrong way, without full international participation.

Great care has been taken to ensure that the three design centres are seen as coequals, although Rebut, now head of the EC's Joint European Torus (JET) project in Culham, England, will work in San Diego. The project's oversight and design integration functions will also be there, although they may rotate as part of a continuing effort to keep the sites equal.

The Garching site, outside Munich, will be responsible for designing the reactor vessel and its contents. That group will be headed by Ronald Parker of the Massachusetts Institute of Technology. The Japanese centre, led by Michel Huguet, also from JET, will design components outside the vessel, including the five-storey-high superconducting magnets that will shape and confine the fusion plasma within the reactor. Yasuo Shimonura of Japan's Atomic
Energy Research Institute will be the project's third deputy director, overseeing design integration from San Diego.

Parker says that he and other scientists have been frustrated by the delays, and that it has been difficult to sustain the project's momentum in the absence of a formal agreement. Ikuo Makino, until last month the director of the technology development division of the Atomic Energy Bureau in Japan's Science and Technology Agency, blames the delay on "cultural" problems among the partners. Although US and European officials enjoy 'hard' negotiations, he says, Japanese shrink from them and the Russians fall in the middle. But he admits that negotiations will become more difficult as the project advances.

With regard to selecting a site, Parker suggests that the reactor may be less of a prize than it appears. The host country will probably pay twice as much as its partners because it will bear the bulk of conventional convention costs. With the United States increasingly sceptical of any large science project and the Russians too poor to afford one, "our nightmare is that no one will want to host it", he says.

Parker has little doubt that the reactor, which will produce a minimum of 1,000 megawatts of fusion power for at least 1,000 seconds, is technically feasible. "The joke around here is that all these machines look the same in an eight-and-a-half by 11 [inch] viewgraph", he says. "It's just the man standing next to it who looks smaller."

Dave Kramer

\section{Hoyle statue unveiled}

London. Many hatchets were elegantly buried last Saturday (18 July) when a bronze statue of Sir Fred Hoyle was unveiled on the grounds of the Institute of Astronomy at the University of Cambridge. Hoyle, from the outset of his academic career a fellow of St Johns College, founded the Institute of Theoretical Astronomy (as it was then called) in the early 1960 s. He resigned his university positions less than a decade later, feeling slighted by the university.

At the unveiling, Hoyle's erstwhile collaborators, Thomas Gold, Hermann Bondi and R.A. Lyttleton, lauded his contributions to astrophysics and cosmology. Hoyle said that the site is peopled by ghosts including that of Eddington, who had plotted the 1919 solar eclipse to within 100 yards, and wistfully wondered whether his own ghost might compare itself with that of others seeking an elusive goal and failing to find it.

John Maddox

\section{Burris appointed to head Woods Hole marine laboratory}

Washington. The Marine Biological Laboratory (MBL) in Woods Hole, Massachusetts, last week abandoned a century-old tradition of electing a working scientist to head the institute by choosing a scientistturned-administrator skilled at raising funds and building consensus.

The choice of John Burris, a 43-year-old marine biologist who has spent the past

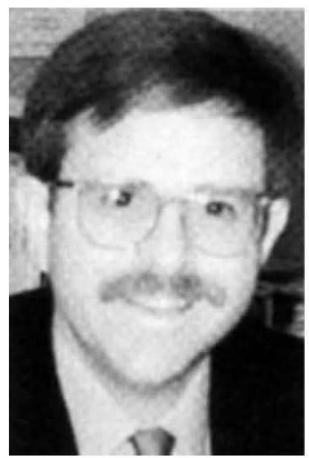

John Burris eight years at the National Academy of Sciences, reflects the problems facing small independent research institutions. $\mathrm{MBL}$ draws the bulk of its financial support from federal grants won by its few year-round researchers, but competition for such grants has grown so fierce that the venerable laboratory, with its small endowment, is struggling to preserve its status as one of the pre-eminent summer research centres. Burris replaces Harlyn Halvorson, who has reached the mandatory retirement age.

Despite the laboratory's difficulties, some members of the search committee wanted to fill the slot with a working scientist. MBL has "always had a practising scientist" as a director, says Roger Sloboda, a cell biologist at Dartmouth College and an MBL trustee. "People assumed that was a given."

But the committee soon realized that a working researcher would be unable to oversee an organization as large and troubled as MBL. So after a year-long search, the committee unanimously selected Burris, who holds a PhD from the Scripps Institution of Oceanography in La Jolla, California. Burris has spent the last eight years as an administrator with the academy's National Research Council, most recently as executive director of its Commission on Life Sciences.

Burris, who takes office as director and chief executive officer in September, says he welcomes the chance to revitalize MBL. "I think it's an exciting position, a challenging position", he says.

Those in the MBL community who know his credentials have faith that Burris can meet the challenge. "MBL is very much in need of astute management", says John Dowling, a neurobiologist at Harvard College who has spent the past 24 summers at the laboratory, "and that's exactly what he's going to provide."

Traci Watson 